University of South Carolina

Scholar Commons

10-1992

\title{
Some Evidence on the Empirical Significance of Credit Rationing
}

\author{
Allen N. Berger \\ University of South Carolina - Columbia, aberger@moore.sc.edu \\ Gregory F. Udell
}

Follow this and additional works at: https://scholarcommons.sc.edu/fin_facpub

Part of the Finance and Financial Management Commons

\section{Publication Info \\ Published in Journal of Political Economy, Volume 100, Issue 5, 1992, pages 1047-1077. http://www.jstor.org/action/showPublication?journalCode=jpoliecon (c) 1992 The University of Chicago Press}

This Article is brought to you by the Finance Department at Scholar Commons. It has been accepted for inclusion in Faculty Publications by an authorized administrator of Scholar Commons. For more information, please contact digres@mailbox.sc.edu. 


\title{
Some Evidence on the Empirical Significance of Credit Rationing
}

\author{
Allen N. Berger \\ Board of Governors of the Federal Reserve System
}

Gregory F. Udell

New York University

This paper examines the credit rationing debate using detailed contract information on over one million commercial bank loans from 1977 to 1988 . While commercial loan rates are "sticky," consistent with rationing, this stickiness varies with loan contract terms in ways that are not predicted by equilibrium credit rationing theory. In addition, the proportion of new loans issued under commitment does not increase significantly when credit markets are tight, despite the fact that borrowers without commitments can be rationed whereas commitment borrowers are contractually insulated from rationing. Overall, the data suggest that equilibrium rationing is not a significant macroeconomic phenomenon.

\section{Introduction}

The subject of credit rationing is the focus of a considerable body of theoretical analysis. One reason for this interest is the potentially

Most of the work on this paper was completed while Udell was a visiting economist at the Federal Reserve Board. The opinions expressed do not necessarily reflect those of the Board of Governors or its staff. We would like to thank the editors and the anonymous referee for guidance in rewriting the paper; Bob Avery, Mitch Berlin, Charles Calomiris, Mark Carey, Lee Crabbe, Jean Dermine, Doug Diamond, John Duca, George Fenn, Bruce Greenwald, Takeo Hoshi, Dick Ippolito, Jarl Kallberg, Anil Kashyap, Loretta Mester, Don Morgan, Len Nakamura, Rich Rosen, Tony Saunders, Steve Sharpe, Joe Stiglitz, Anjan Thakor, Paul Wachtel, and Arthur Warga for helpful comments; and John Leusner, Peter Zemsky, and Bill Glahn for invaluable research assistance. 
important role that credit rationing may play in the transmission of monetary policy. Advocates of the availability doctrine in the $1950 \mathrm{~s}$ suggested that monetary policy may operate in part through a rationing channel rather than an interest rate channel (e.g., Kareken 1957; Scott 1957). This early work on credit rationing depended on ad hoc price rigidity arguments for its motivation. Later work by Jaffee and Russell (1976) and Stiglitz and Weiss (1981) demonstrated that credit rationing may persist in equilibrium using informationbased models. These papers spawned an entire generation of work on credit rationing based on an information-theoretic approach (e.g., Blinder and Stiglitz 1983; Wette 1983; Besanko and Thakor 1987a, 1987b; Williamson 1987).

Despite these theoretical efforts, there remains little consensus about whether credit rationing is an economically significant phenomenon. Riley (1987) argued that credit rationing in a Stiglitz-Weiss environment would be limited to the marginal class of observably distinct risk pools. Stiglitz and Weiss (1987) countered that Riley's result was model-specific rather than general. Others have argued that contractual mechanisms may be available that mitigate the rationing problem. These mechanisms include loan commitments (see Boot and Thakor 1989; Sofianos, Wachtel, and Melnik 1990) and collateral (see Bester 1985; Chan and Kanatas 1985; Besanko and Thakor 1987b). Given the reasoned arguments on all sides of this issue, it is clear that the significance or insignificance of credit rationing will have to be established empirically.

Unfortunately, empirical tests of the extant theories of equilibrium credit rationing have been difficult to conduct because of the paucity of micro data on the contractual terms of commercial bank loans. Nevertheless, some evidence has been generated on this issue using macro data. Most of this research has exploited the fact that a key testable implication of credit rationing is that the commercial loan rate is "sticky"; that is, it does not fully respond to changes in openmarket rates. Often this research has focused on the speed with which the loan rate adjusts to market rates. Goldfeld (1966) and Jaffee (1971) found that the commercial loan rate was slow to adjust to open-market rate changes. Slovin and Sushka (1983) later found that the commercial loan rate was less "sticky" than in Goldfeld's or Jaffee's results and took this as evidence against the credit rationing hypothesis, although their result may be subject to an alternative interpretation. ${ }^{1}$ Using a different approach, King (1986, p. 298) found

\footnotetext{
${ }^{1}$ Slovin and Sushka regressed the average commercial loan interest rate on the contemporaneous value and two quarterly lags of the commercial paper rate, using nine different specifications of other variables (their table 1, p. 1590). The coefficient of the second lag term was statistically significant at the 1 percent level in six of nine
} 
"mixed support" for the credit rationing hypothesis. Sofianos et al. (1990) used time-series techniques and found evidence consistent with credit rationing, but only for loans funded without commitments. As discussed below, however, their results may also be subject to an alternative interpretation.

This paper differs from previous empirical work on credit rationing of commercial loans in that individual loan data, rather than macro data, are employed. The micro data approach permits us to analyze the empirical implications of rationing models that relate to specific features of bank loan contracts and to examine the behavior of the commercial loan market at the individual loan level. The Federal Reserve's Survey of Terms of Bank Lending data set contains contract information on over 1,000,000 commercial loans made from 1977 to $1988 .^{2}$

Consistent with previous studies, we find evidence of loan rate stickiness. In contrast to previous studies, however, we do not assume that this necessarily reflects credit rationing. While sticky loan pricing is consistent with the rationing hypothesis, it is not by itself sufficient evidence of it. One alternative explanation is that banks may offer implicit interest rate insurance to risk-averse repeat borrowers in the form of below-market rates during periods of high market rates, for which the banks are later compensated when market rates are low (see Fried and Howitt 1980). Another possibility is that stickiness may be the result of loan recontracting between banks and companies experiencing financial distress when market interest rates are high. To avoid bankruptcy costs, banks may be willing to renegotiate and grant new loans at concessionary rates to such companies at these times (see Sharpe 1991).

In this paper, we develop a number of empirical tests that are capable of differentiating credit rationing from alternative explanations of price stickiness in commercial lending. We examine how loan rate stickiness varies across several loan contract features that may be related to rationing behavior. In addition, a more direct and definitive test of the quantitative effects of rationing focuses on the propor-

cases. They concluded that "movements in interest rates are fully and quickly transmitted to commercial loan customers" (p. 1595), but an alternative conclusion is that the transmission mechanism takes at least two quarters and perhaps more.

${ }^{2}$ There have also been a number of studies of credit rationing in the mortgage market. Duca and Rosenthal (1991) examined the behavior of the ratio of Federal Housing Administration (FHA) mortgages to total mortgages in the "post-disintermediation era," arguing that FHA mortgages are less vulnerable to rationing because they are government guaranteed. They found evidence of "default-risk induced" ra" tioning in the form of a positive relationship between FHA market share and the spread of AAA- over A-rated corporate bonds. See also Jaffee and Rosen (1979), Hendershott (1980), and Rosen and Rosen (1980). 
tion of new loans that are issued under commitment. If rationing were widespread, this proportion would necessarily increase when credit markets are tight because borrowers without commitments can be rationed whereas commitment borrowers are contractually insulated from rationing.

The paper proceeds as follows. Section II describes the data and the tests to be performed, and Section III gives the empirical results of those tests. Section IV presents conclusions.

\section{Data and Test Descriptions}

Our primary data source is the Federal Reserve's Survey of Terms of Bank Lending. Each quarter from 1977:1 to 1988:2, approximately 340 banks listed the individual characteristics of every domestic commercial and industrial loan and construction and land development loan made during one or more days of the first week of the second month of the quarter. The sample includes the 48 largest banks in the nation in terms of commercial and industrial lending plus 292 other banks chosen to represent the strata of smaller banks. Banks that withdrew from the sample were replaced with banks of similar size and other characteristics. In all, 460 different banks are represented in the sample.

Table 1 gives a description of each variable, as well as its sample mean, standard deviation, and number of independent observations. ${ }^{3}$ The data set is quite large, with $1,103,933$ independent observations on the terms of individual loans taken from 460 different banks and 46 time periods. The bank and macro variables, which have fewer independent observations, were allocated to their corresponding loan observations.

\section{Tests of Loan Rate Stickiness}

The "stickiness tests" involve regressing the loan rate premium (PREM) against measures of real or nominal rates, the key loan contract variables, and a number of control variables for characteristics of the loan contract, the issuing bank, and the macro environment. For fixed-rate loans, PREM is the annualized (nominal) loan interest rate less the (nominal) rate on a Treasury security of comparable duration. For floating-rate loans, we ideally would subtract the Treasury rate with duration equal to the expected repricing interval, but this cannot be precisely determined from the data. As an approxima-

${ }^{3} \mathrm{~A}$ small number of loans (fewer than 1 percent) were deleted because of data problems. See Berger and Udell (1989) for details. 
tion, we assume that all floating rate loans are expected to be repriced within 4 weeks and use the Treasury rate with duration equal to the minimum of the loan duration and 4 weeks. ${ }^{4}$

The primary exogenous variables are the comparable Treasury rate for each loan (TRATE) and its square (TRATE2), which measure open-market rates and summarize credit market conditions relevant to rationing. Note that the use of PREM and the TRATE variables allows for nonlinearities in the term structure of interest rates, which would not be the case if the loan rate were used instead as the dependent variable and a single representative Treasury rate and the loan duration were included as regressors. A second measure of credit market tightness is the dummy variable CRUNCH, which takes on the value one for quarters in which Eckstein and Sinai (1986) determined that a credit crunch was operative. This variable allows for additional nonlinear effects of credit market conditions and allows us to focus particularly on the time periods in which rationing may have been most likely to occur. ${ }^{5}$

The analysis was conducted using both real and nominal interest rates as exogenous variables, denoted by TRATER and TRATEN, respectively. This represents a break from the empirical literature, which generally considers only nominal rates. Note that the dependent variable PREM does not depend on real versus nominal considerations, since it is the difference between two rates of the same duration. The use of the real rate (TRATER) more closely corresponds with the theoretical literature on credit rationing, which essentially describes a real phenomenon. Unfortunately, use of the real rate suffers in practice because inflationary expectations are unknown. In estimating inflationary expectations, we tried models of both rational and adaptive expectations as well as the Livingston Survey data. Since the results were similar across approaches, we simply report the results from using the Livingston data here. Use of the nominal rate (TRATEN) has the virtue of largely avoiding mismeasurement problems, but it may fail to capture effectively the changes in credit market tightness. However, to the extent that some economic agents react to

\footnotetext{
${ }^{4}$ For the 4-week rate, we used the average of the bid-asked spread in the secondary Treasury bill market. The other Treasury data used were new issue (when available) or secondary market quotes of 3- 6-, and 12-month bills and 2-, 3-, 5-, 7-, 10-, and 30 -year bonds and notes. Durations were computed for these maturities, and the rates for all other durations were determined by interpolation and extrapolation. A number of other methods of computing the risk premia on floating-rate loans were tried, but the reported results were not qualitatively altered.

${ }^{5}$ Eckstein and Sinai defined credit crunches as "periods when financial distress produces sharp discontinuities in flow of funds and spending and when the financial strains include tight monetary policy, much lessened availability of money and credit, sharp rises of interest rates, and deteriorating balance sheets for households, businesses, and financial institutions" (p. 41).
} 
TABLE 1

DATA USED IN REGRESSIONS

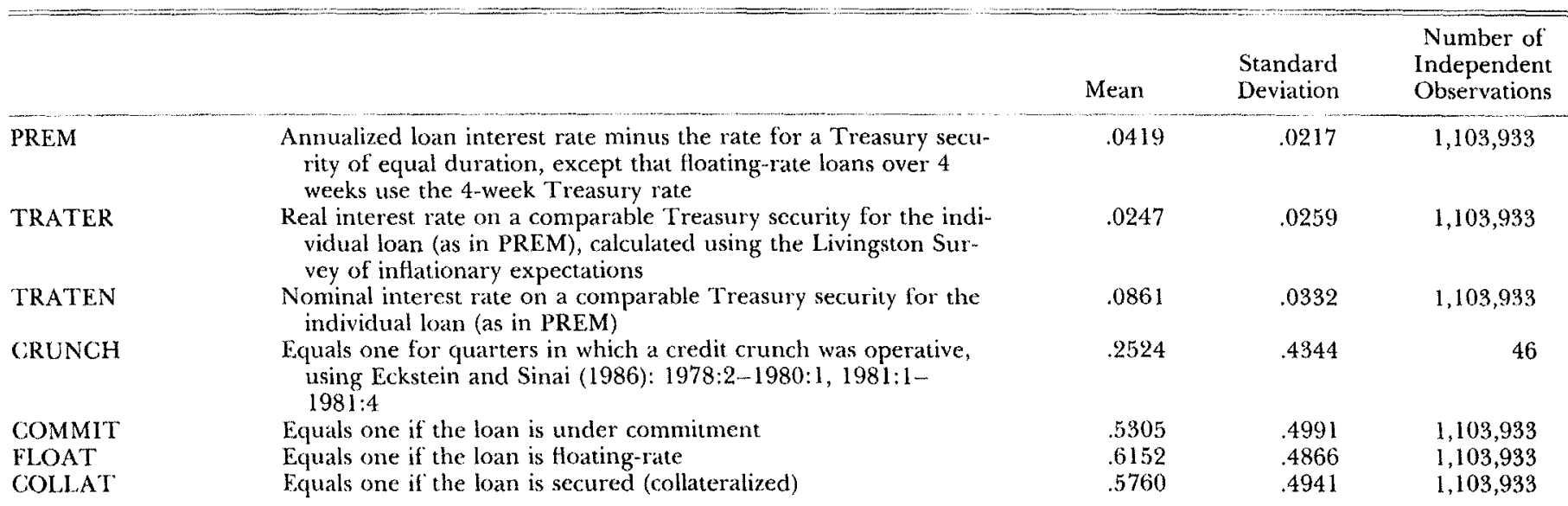


SIZE

DURATION

DEMAND

OVERNIGHT

SINGFAM

MULTIFAM

NONRES

LNBANKASSETS

GNPGROWTH

- UNEMPLOY

o TIME

BANKDUMMIES
Real size of the loan (LNSIZE $=\log [$ SIZE] used in regressions)

Duration of the loan in years; the present-value weights use the initial loan interest rate (LNDURATION $=\log [$ DURATION] used in the regressions)

Equals one if the loan has no stated maturity (i.e., a demand note)

Equals one if the loan is a 1-day (i.e., overnight) loan; set to zero prior to August 1982, when day of month maturities became available

Equals one for a single-family construction and development loan

Equals one for a multifamily construction and development loan Equals one for a nonresidential construction and development loan

Natural logarithm of the total assets of the bank

Real GNP growth over the previous quarter (\%)

Unemployment rate (\%)

Time trend for the 46 dates $(1, \ldots, 46)$

Dummies for all sample banks were included in every regression 
changes in nominal prices because of nominal price stickiness in output or factor markets or because of difficulties in contracting in real rates, nominal rate stickiness may still be indicative of credit rationing.

In contrast to some of the empirical literature (e.g., Goldfeld 1966; Jaffee 1971; Slovin and Sushka 1983), we use only contemporaneous open-market interest rates and do not include lags. In our opinion, this provides a cleaner test of the Jaffee and Russell (1976) and Stiglitz and Weiss (1981) models of equilibrium credit rationing. These are one-period models of lender responses to current credit market conditions. Therefore, the current comparable Treasury rate for the loan and its square seem to be good summary statistics for the conditions relevant to the setting of rates and rationing policies on newly issued loans. Thus the model tests whether, in equilibrium, banks raise loan rates equally with increases in risk-free open-market rates or whether they ration loan funds, not how long it takes to reach equilibrium.

In some of the regression models, the credit market tightness variables TRATE and CRUNCH are interacted with three key contract variables, COMMIT, COLLAT, and FLOAT, in order to determine whether loans with different contract terms exhibit different degrees of stickiness. Under a loan commitment contract, the lender agrees to extend credit at the borrower's request up to some prespecified amount over a given time period. Commitments explicitly provide insurance against credit rationing because they preclude the bank from denying a funding request on the basis of general market conditions (see Melnik and Plaut 1986; Sofianos et al. 1990). ${ }^{6}$ Indeed, a recent loan officer survey (Board of Governors 1988) indicated that "protection against credit crunches" ranked only behind minimizing transactions costs as a motivation for commitments. Therefore, any observed stickiness on commitment loans cannot reflect credit rationing of commitment borrowers, since they are contractually insulated from rationing.

The difference in stickiness between commitment and noncommitment loan rates may also reflect the difference in relative magnitudes of information problems between commitment and noncommitment borrowers and in the power of micro contracting to solve these problems. A study of loan commitments found commitment loans to be safer on average than noncommitment loans, suggesting that commitment borrowers may have fewer than average information problems

\footnotetext{
${ }^{6}$ Many commitments have escape clauses that permit the lender to abrogate the contract in the event that the borrower's condition has suffered "material adverse change." These clauses by necessity are triggered by changes in the observable quality of the borrower. Therefore, commitments with escape clauses still provide insurance against Stiglitz and Weiss-type rationing, which is driven by unobservable differences in borrower quality.
} 
(see Avery and Berger 1991), although in some tangentially related research, commitments are not negatively related to all the risk measures (see Berger and Udell 1990, 1992). The nature of the commitment contract or the commitment selection process might also attenuate the kinds of information problems that have typically been associated with credit rationing (see Boot, Thakor, and Udell 1987; Kanatas 1987; Thakor and Udell 1987; Berkovitch and Greenbaum 1991). Thus if information problems are creating the stickiness, it is likely that commitment loan rates would be less sticky, reflecting fewer information problems for commitment borrowers or the attenuation of these problems by the commitments.

Collateral has been found to be associated with higher risk and therefore may be associated with more information problems and loan rate stickiness (see Berger and Udell 1990). However, the pledging of collateral can also mitigate information problems, reducing the associated stickiness (see Bester 1985; Chan and Kanatas 1985; Besanko and Thakor $1987 a, 1987 b$ ). Thus rates on secured loans may be more or less sticky than unsecured loans. Finally, floating-rate loans may have a different degree of stickiness than fixed-rate loans because of any sorting associated with the degree of fixity in rate repricing or differences related to the sharing of interest rate risk.

\section{Tests of the Proportions of Loans with Different Contract Features}

The "proportions tests" examine the testable implications of credit rationing that relate to how the proportions of new loans with different contract features vary with credit market tightness. The methodology is to form logit models of the probabilities that one dollar being lent for 1 year will (i) be under commitment, (ii) be secured, or (iii) be floating rate. Computing limitations rule out the possibility of using observation-by-observation logit estimations, so grouped logit models were formed by combining the loans made by a given bank at a given time. For every variable for which data were available by individual loan, a weighted average across all the loans for the bank-date combination was formed, with the weights being proportional to the size and duration of the individual loans. In this way, each loan is represented in proportion to its contribution to the bank's future loan portfolio. ${ }^{7}$ The dependent variables were also transformed into logodds ratio form $\ln [Y /(1-Y)]$, where $Y$ is the size-duration weighted proportion of new loans with the characteristic being examined (e.g.,

\footnotetext{
${ }^{7}$ For example, a $\$ 5,000$ loan with 2 years' duration receives 10 times the weight of a $\$ 1,000,1$-year loan.
} 
COMMIT). This form preserves the functional relationship of the observation-by-observation logit form but loses some information by averaging. Each regression was estimated by weighted least squares to avoid heteroskedasticity problems. ${ }^{8}$

The COMMIT proportions test provides a relatively direct and definitive test of the quantitative significance of credit rationing. If credit rationing is economically important, then the proportion of new bank loans made under commitment must increase substantially with open-market rates and credit market tightness. Simply put, rationing decreases the quantity of noncommitment lending from what it otherwise would have been but cannot reduce the quantity of commitment lending because of contractual constraints. ${ }^{9}$ Two other factors related to information problems may also induce a positive relationship between open-market rates and the commitment proportion even if no rationing actually occurs: (i) borrowers may avoid rationing by switching funding from noncommitment sources to existing commitment lines (if not deterred by commitment covenants) or (ii) more borrowers may purchase commitment contracts when the probability of being rationed is increased. ${ }^{10}$ It follows that a virtual necessary, but not sufficient, condition for rationing to be an important macroeconomic phenomenon is that the proportion of new loans made under commitment increases substantially when open-market interest rates rise.

The COLLAT and FLOAT proportions tests are intended to reveal the extent to which rationing, if it occurs, affects borrowers with different contract terms differently. For instance, how the COLLAT proportion reacts to changes in open-market interest rates may reveal the net effect of (i) the difference in information problems for secured versus unsecured borrowers, (ii) the extent to which collateral arrangements solve these problems, and (iii) the extent to which bor-

${ }^{8}$ Each observation was divided by the estimated standard deviation of its error term, $(\{(1 / Y)+[1 /(1-Y)]\} / n)^{1 / 2}$, where $n$ is the sum of the size-duration weights for all the loans embodied in the bank-date observation.

${ }^{9}$ The only case in which rationing would not be reflected in the proportion of loans made under commitment would occur if rationing were demand-induced and the increased demand came only from noncommitment borrowers. In this case, there would be excess demand for noncommitment loans, but the quantities of both commitment and noncommitment loans would remain constant. Although possible, this case seems quite unlikely. Increases in aggregate demand are generally associated with increased funding under working capital commitment lines to finance inventory replenishment, so that, if anything, the commitment proportion would increase.

${ }^{10}$ This latter argument assumes that there are some fixed costs associated with issuing commitments that do not generally increase with the probability of takedown. An example might be the expected costs associated with the difficulty of writing a "material adverse change clause" that adequately protects the bank against borrower credit deterioration. Without fixed costs, risk-averse borrowers would always purchase commitments from risk-neutral banks. 
rowers who do not pledge collateral when rates are low may pledge collateral when rates are high to avoid rationing.

Both the stickiness and the proportions regressions include a number of additional loan-specific, macro, and bank variables as control variables. The loan-specific contract variable LNSIZE accounts for the possibility of scale economies in lending and the possibility that loan size may also be associated with credit risk; LNDURATION accounts for the possibility of a nonrisk term premium component of the dependent variable or another scale economy in lending; $\mathrm{DE}$ MAND accounts for differences in risk created by the bank's option to call a loan and any sorting effects related to this option. The OVERNIGHT, SINGFAM, MULTIFAM, and NONRES variables are exogenous factors that may provide information about the type of borrower or loan. The macro variables, GNPGROWTH, UNEMPLOY, TIME, and the square of TIME, are included to control for the effects of non-credit market cycles, changes in aggregate risk, and other trends that may be correlated with credit market conditions. The bank variable LNBANKASSETS is included to account for the possibility of segmented markets in which different-sized banks have access to different types of borrowers. Finally, every regression contains dummy variables for every bank in the sample to control for systematic differences in pricing caused by the presence of other pricing elements (e.g., up-front fees or compensating balances), as well as differences in regulatory and competitive environments across banks. The use of the individual bank dummies essentially provides the strongest set of controls for any type of stable bank differences that can be specified.

\section{Empirical Results}

\section{Stickiness Test Results}

Tables 2 and 3 show the results of the stickiness tests. The loan rate premia (PREM) are regressed on real and nominal rates, respectively, as well as loan contract terms and macro and bank control variables, although the coefficients of the control variables are not shown here (see Berger and Udell [1989] for these coefficients). All coefficients and derived statistics (including the coefficients of the control variables) are statistically significant because of the unusually large number of observations. The regression shown in column 1 of table 2 has as regressors the real Treasury rate appropriate for the individual loan (TRATER) and its square (TRATER2), but excludes CRUNCH and any interaction terms. The individual coefficients of TRATER and TRATER2 are difficult to interpret because the variables move 
TABLE 2

Regressions of Loan Rate Premia (PREM) on Real In'terest Rates, Loan Contract Terms, and Control Variables

\begin{tabular}{|c|c|c|c|c|c|c|c|c|c|c|}
\hline \multirow[b]{2}{*}{ Variable } & \multirow{2}{*}{$\frac{\text { Coefficient }}{\text { (1) }}$} & \multirow[t]{2}{*}{ Statistic } & Coefficient & \multirow[t]{2}{*}{$t^{t-}$} & \multirow{2}{*}{\multicolumn{2}{|c|}{ Coefficient }} & \multirow{2}{*}{\multicolumn{2}{|c|}{$\begin{array}{l}\text { Coefficient } \\
\text { (4) }\end{array}$}} & \multirow{2}{*}{$\frac{\text { Coefficient }}{(5)}$} & \multirow[t]{2}{*}{$\begin{array}{c}t- \\
\text { Statistic }\end{array}$} \\
\hline & & & (2) & & & & & & & \\
\hline TRATER & $-.4912^{* *}$ & -239.3 & $-.5973^{* *}$ & -249.0 & $-.6452 * *$ & -259.8 & $-.5392 * *$ & -220.5 & $-.5930 * *$ & -234.9 \\
\hline TRATER2 & $3.4176^{* * *}$ & 150.7 & $3.6801 * *$ & 161.5 & $3.8687^{* *}$ & 169.4 & $3.6795 * *$ & 162.0 & $3.8555^{* *}$ & 169.5 \\
\hline CRUNCH & & & & & $-2.2 E-4^{*}$ & -2.5 & & & $.0044 * *$ & -46.2 \\
\hline TR-COM-FLOAT & & & $.1289^{* *}$ & 76.7 & $.1089 * *$ & 64.2 & & & & \\
\hline TR-COM-FIXED & & & $.0379 * *$ & 17.2 & $.0288^{*} * *$ & 13.1 & & & & \\
\hline TR-NOCOM-FLOAT & & & $.1436^{* *}$ & 75.9 & $.1292 *$ & 67.9 & & & & \\
\hline TR-COL-FLOAT & & & & & & & $.0740 * *$ & 41.6 & $.0694 * *$ & 38.7 \\
\hline TR-COL-FIXED & & & & & & & $-.1062 * *$ & -52.9 & $-.0971 * *$ & -48.5 \\
\hline IR-NOCOL-FLOAT & & & & & & & $.0842 * *$ & 43.1 & $.0633^{* *}$ & 32.1 \\
\hline CR-COM-FLOAT & & & & & $.0112 * *$ & 107.8 & & & & \\
\hline CR-COM-FIXED & & & & & $.0060^{* * *}$ & 46.9 & & & & \\
\hline CR-NOCOM-HIOAT & & & & & $.0085 * *$ & 73.5 & & & & \\
\hline CR-COL-FLOAT & & & & & & & & & $.0043 * *$ & 39.1 \\
\hline CR-COL-FIXED & & & & & & & & & $-.0066^{* *}$ & -57.2 \\
\hline CR-NOCOL-FLOAT & & & & & & & & & $.0074 * *$ & 60.9 \\
\hline COMMIT' & $-.0030 * *$ & -71.1 & & & & & $-.0032 * *$ & -76.1 & $-.0031 * *$ & -74.1 \\
\hline COLLAT & $9.9 \mathrm{E}-4^{* *}$ & 25.0 & $.0011 * *$ & 27.8 & $.0010 * * *$ & 25.9 & & & & \\
\hline FLOAT & $.0081 * *$ & 178.1 & & & & & & & & \\
\hline COM-ILLAT & & & $.0015^{* * *}$ & 20.8 & $-.0016^{* *}$ & -20.6 & & & & \\
\hline COM-FIXED & & & $\cdots-.0043 * *$ & -50.7 & $-.0062 * *$ & -68.4 & & & & \\
\hline NOCOM-FLOAT & & & $.0040^{* * *}$ & 53.0 & $.0012 * *$ & 15.4 & & & & \\
\hline COL-FLOAT & & & & & & & $.0064^{* *}$ & 86.3 & $.0051^{* *}$ & 64.5 \\
\hline COI-lIXED & & & & & & & $6.7 \mathrm{E}-4^{* *}$ & 8.8 & $.0026^{* * *}$ & 31.0 \\
\hline
\end{tabular}


NOCOL-FLOAT

$R^{2}$
.28 .28

Simulated Effects of an Increase in Credit Market Tightness:

Predicted Change in PREM and $t$-Statistic from a Doubling of TRATER from Its Mean (.02472) for Different Categories of Loans

COM- or COL-

FLOAT LOANS

COM- OR COL-

FIXED LOANS

NOCOM-OR

NOCOL-FLOAT LNS

NOCOM-OR

NOCOL-FIXED LNS

$-.0059^{* *} \quad-249.6$

$$
-.0048 * * \quad-149.8 \quad-.0062 * *-182.3
$$

$-.0048 * *$

$-145.2$

$-.0059 * *$

$-.0092^{* *} \quad-218.2$

$-.0100 * *$

$-.0045^{* *} \quad-120.8 \quad-.0060^{* *}$

$-.0057 * *-140.9$

$-0066^{* *}-173.6$

$-.0076 * *$

$-.0089 * \quad-240.9$

$-.0066^{* *}$

$-173.6$

$-192.8$

Predicted Change in PREM and $t$-Statistic from a Credit Crunch (CRUNCH) for Different Categories of Loans

$\div$ COM-OR COL.

FLOAT LOANS

COM-OR COL-

FIXED LOANS

NOCOM-OR

NOCOL-FLOAT LNS

NOCOM-OR

NOCOL-FIXED LNS

\begin{tabular}{|c|c|c|c|}
\hline $.0109 * *$ & 117.4 & $.0086^{* *}$ & 93.5 \\
\hline $.0058^{* * *}$ & 48.1 & $-.0023^{* *}$ & -22.8 \\
\hline $.0082 *$ & 77.5 & $.0117 * *$ & 110.5 \\
\hline$-2.2 \mathrm{E}-4^{*}$ & -2.5 & $.0044^{* *}$ & 46.2 \\
\hline
\end{tabular}

NoTE, - Each observation represents the terms of an individual loan contract. Number of observations is 1,103,933. Intercepts were included for each bank in the sample, and the $R^{2}$ 's reflect the proportion of variance explained after these intercepts. Also included but not shown are the control variables LNSIZE, LNDURATION, DEMAND, OVERNIGHT, SINGFAM, MULTIFAM, NONRES, LNBANKASSETS, GNPGROWTH, UNEMPLOY, TIME, and TIME2.

* Statistically significant at the 5 percent level, two-sided.

** Statistically significant at the 1 percent level, two-sided. 
TABLE 3

Regressions of loan Rate Premia (PRlM) on Nominal Interest Rates, Loan Contract Tlerms, and Con'trol Variables

\begin{tabular}{|c|c|c|c|c|c|c|c|c|c|c|}
\hline \multirow[b]{2}{*}{ Variable } & Coefficient & $\begin{array}{c}\ell- \\
\text { Statistic }\end{array}$ & \multirow{2}{*}{\multicolumn{2}{|c|}{$\frac{\text { Cocfficient }}{(2)}$}} & Cocfficient & $\begin{array}{c}t- \\
\text { Statistic }\end{array}$ & Cocfficient & $\begin{array}{c}t^{-} \\
\text {Statistic }\end{array}$ & \multirow{2}{*}{\multicolumn{2}{|c|}{$\frac{\text { Cocfficient Statistic }}{(5)}$}} \\
\hline & \multicolumn{2}{|c|}{ (1) } & & & \multicolumn{2}{|l|}{ (3) } & \multicolumn{2}{|c|}{ (4) } & & \\
\hline TRATEN2 & $.5819 * *$ & 29.8 & $.8520 * *$ & 43.9 & $.7787 * *$ & 40.0 & $.7624 * *$ & 39.4 & $.6945 * *$ & 35.8 \\
\hline CRUNCH & & & & & $-.0012 * *$ & -12.6 & & & $.0016^{* *}$ & 16.0 \\
\hline TR-COM-FLOAT & & & $.1834 * *$ & 131.8 & $.1429 * *$ & 89.3 & & & & \\
\hline TR-COM-FIXED & & & $.0946 * *$ & 51.2 & $.0699 * *$ & 33.8 & & & & \\
\hline TR-NOCOM-FLOAT & & & $.1778 * *$ & 113.9 & $.1550^{* * *}$ & 86.0 & & & & \\
\hline TR-NOCOL-FLOAT & & & & & & & $.1167 * *$ & 73.3 & $.0898^{* *}$ & 48.4 \\
\hline CR-COM-FLOAT & & & & & $.0065 * *$ & 53.5 & & & & \\
\hline CR-COM-FIXED & & & & & $.0040^{* *}$ & 26.9 & & & & \\
\hline CR-NOCOM-FLOAT & & & & & $.0037 * *$ & 27.5 & & & & \\
\hline CR-COL-FLOAT & & & & & & & & & $.0015 * *$ & 11.7 \\
\hline CR-COL-FIXED & & & & & & & & & $-.0039 * *$ & -29.2 \\
\hline CR-NOCOL-FLOAT & & & & & & & & & $.0040^{* *}$ & 28.0 \\
\hline COMMrT & - & -67.8 & & & & & $.0031 * *$ & -72.6 & $-.0030 * *$ & -71.1 \\
\hline COL-FLOAT & & & & & & & $9.8 \mathrm{E}-4 * *$ & 6.7 & $.0013^{* *}$ & 8.8 \\
\hline
\end{tabular}


COL-FIXED

NOCOL-FLOAT

$R^{2}$

\begin{tabular}{rrrrrr} 
& & $.0094 *$ & 57.1 & $.0084^{* *}$ & 50.2 \\
.24 & & $0094 *$ & $-.0035^{* *}$ & -21.3 \\
\hline
\end{tabular}

Simulated Effects of an Increase in Credit Market Tightness:

Predicted Change in PREM and $t$-Statistic from Increasing TRATEN from Its Mean (.08608) by .02472 for Different Categories of Loans

\begin{tabular}{|c|c|c|c|c|c|c|c|c|c|c|}
\hline $\begin{array}{l}\text { COM- or COL- } \\
\text { FLOAT LOANS }\end{array}$ & & & $-.0024^{* *}$ & -68.7 & $-.0032 * *$ & -84.0 & $-.0026^{* *}$ & -75.6 & $-.0031^{* * *}$ & -81.2 \\
\hline COM-OR COL- & & & & & & & & & & \\
\hline $\begin{array}{l}\text { FIXED LOANS } \\
\text { NOCOM-OR }\end{array}$ & $-.0037^{* *}$ & -120.1 & $-.0046^{* * *}$ & -96.6 & $-.0050^{* *}$ & -97.2 & $-.0080^{* *}$ & -185.5 & $-.0076^{* * *}$ & -165.6 \\
\hline NOCOL-FLOAT LNS & & & $-.0025 * *$ & -65.8 & $-.0029 * *$ & -67.3 & $-.0019^{* *}$ & -49.8 & $-.0028 * *$ & -65.5 \\
\hline NOCOM-OR & & & & & & & & & & \\
\hline NOCOL-FIXED LNS & & & $-.0069^{*}$ & -179.4 & $-.006 \%$ & -165.4 & $-.0048^{* 6}$ & -119.8 & $-.0050 \mathrm{~m}$ & -118.1 \\
\hline & & edicted $C$ & ge in PREM & d $t$-Statist & om a Credit & runch $(\mathrm{Cr}$ & CH) for Diff & ent Categ & es of Loans & \\
\hline COM- OR COL- & & & & & & & & & & \\
\hline FLOAT LOANS & & & & & $.0053^{* *}$ & 50.9 & & & $.0031^{* * *}$ & 30.6 \\
\hline COM- OR COL- & & & & & & & & & & \\
\hline FIXED LOANS & & & & & $.0028 * *$ & 20.6 & & & $-.0022 * *$ & -20.2 \\
\hline NOCOM-OR & & & & & & & & & & \\
\hline NOCOL-FLOAT LNS & & & & & $.0025 * *$ & 20.8 & & & $.0056^{* *}$ & 46.3 \\
\hline NOCOM-OR & & & & & & & & & & \\
\hline NOCOL-FIXED LNS & & & & & $-.0012 * *$ & -12.6 & & & $.0016^{* *}$ & 16.0 \\
\hline
\end{tabular}

Note,-See note to table 2.

** Statistically significant at the 1 percent level, two-sided. 
together, but their coefficients have opposite signs. To obtain a more meaningful summary statistic that measures the effects of a tightening of the credit market, we computed the predicted change in PREM that would be caused by a doubling of TRATER from its mean (i.e., from 2.472 percent to 4.944 percent). The predicted change and its $t$-statistic are shown in column 1 of the bottom section of the table. The -.0059 predicted change suggests that when real rates double, the premium over the risk-free rate drops 59 basis points. ${ }^{11}$ This represents a substantial degree of stickiness in loan rates when compared to the historical average bank return on assets, which is less than 100 basis points. The elasticity of PREM with respect to TRATER evaluated at the sample mean is also substantial, -.19 .

The regression shown in column 1 of table 3 repeats the experiment using nominal Treasury rates (TRATEN, TRATEN2) in place of the real rates. When nominal rates are increased by the same amount as the real rates (2.472 percent), the measured stickiness is somewhat less, 37 basis points. This becomes much larger, 99 basis points (not shown), if nominal rates are instead doubled from their relatively large sample mean value ( 8.608 percent). We consider the lesser of these two increases to be more reliable, since twice the mean nominal rate is well above the dense part of the TRATEN distribution. The elasticity of PREM with respect to the nominal rate evaluated at the mean is -.34 , which exceeds (in absolute value) the real rate elasticity because of the larger mean of TRATEN. ${ }^{12}$

Figure 1 illustrates the relationships between the loan rate premia and Treasury rates over time. The solid lines in the figure connect the size-duration weighted averages of PREM across all loans for each time period; the broken lines connect the weighted averages of TRATER in figure $1 a$ and TRATEN in figure $1 b$. As shown, PREM is very highly negatively correlated with both real and nominal rates over the period from about $1979: 4$ to $1982: 4$ but is not highly related for the remainder of the sample. During this period, rates were at highs relative to the recent past, then fell and rose again to their sample peaks. The strong negative relationship during this period is consistent with credit rationing but is also consistent with the alternative theories of rate stickiness.

By construction, the stickiness illustrated thus far is the same for

"The formula for this change is $(2 \mu-\mu) \beta_{1}+\left[(2 \mu)^{2}-\mu^{2}\right] \beta_{2}$, where $\mu$ is the sample mean of TRATE and $\beta_{1}$ and $\beta_{2}$ are the coefficients of TRATE and TRATE2, respectively.

${ }^{12}$ Note that the stickiness results would be essentially unchanged if the second-order terms (TRATE2) were not included in the regressions. Excluding these terms gives measured drops in PREM from changing TRATE of 53,31, and 107 basis points in place of the reported 59,37 , and 99 basis points, respectively. 


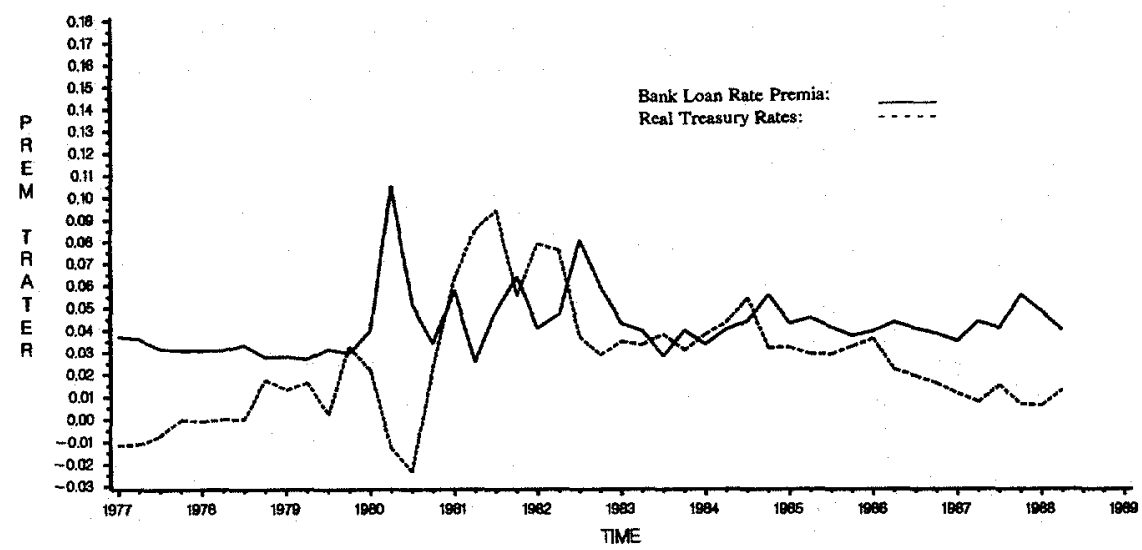

b

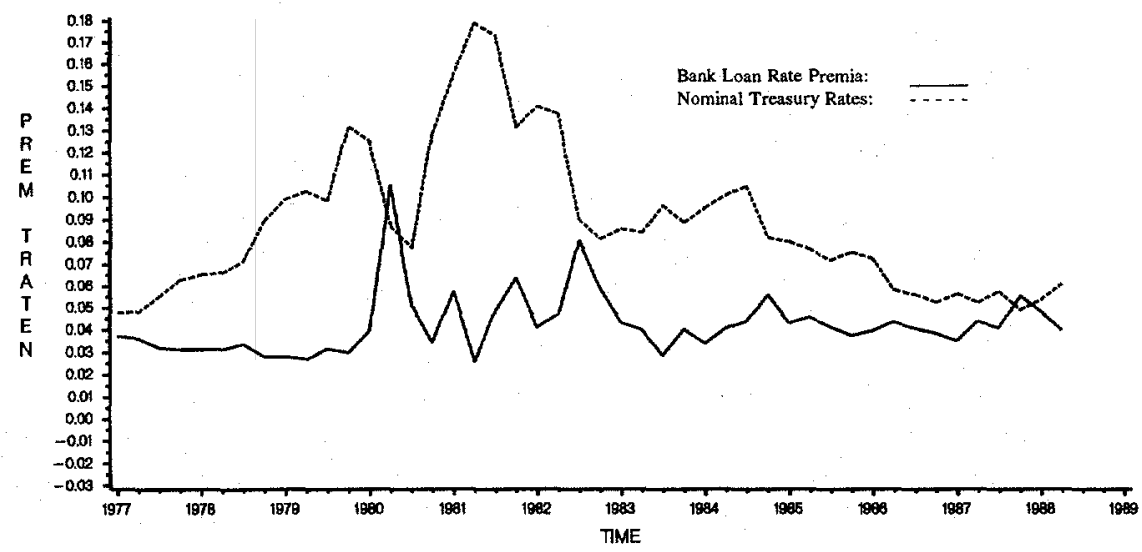

Fig. 1.-Bank loan premia and Treasury rates of the same duration (1977:11988:2): $a$, real Treasury rates; $b$, nominal Treasury rates.

all types of loans since TRATE was not interacted with any other variables in the regressions. However, as discussed above, most of the interesting testable implications apply to relative stickiness, which we turn to next. The regression shown in column 2 of table 2 reproduces the regression in column 1 but allows stickiness to differ across loans in four categories of commitment and floating-rate status. The dummy variables COMMIT and FLOAT are replaced by three interaction terms, COM-FLOAT, COM-FIXED, and NOCOM-FLOAT, and these variables are interacted with TRATE, denoted by TR- 
COM-FLOAT, TR-COM-FIXED, and TR-NOCOM-FLOAT. This allows the four commitment-rate type combinations (including the unspecified category NOCOM-FIXED) to have independent degrees of stickiness. The results in column 2 suggest that all four categories of loans have sticky rates. When real rates are doubled, commitment loans have roughly the same stickiness as noncommitment loans for a given rate type ( 48 vs. 45 basis points for floating-rate and 71 vs. 80 basis points for fixed-rate), but floating-rate loans are substantially less sticky than fixed-rate loans for a given commitment status (48 vs. 71 basis points for commitment and 45 vs. 80 basis points for noncommitment). Column 3 replicates column 2 but adds the variable CRUNCH and its interactions with the other variables as well. The results show that during periods designated as credit crunches, the PREM actually increased for three of the four categories, contrary to the expectation under credit rationing that premia would be lower during credit crunches. In addition, an interaction term between TRATER and CRUNCH added to the regression (not shown) had a positive coefficient, suggesting that the responsiveness of loan rates to open-market rates is greater during credit crunches, again contrary to expectations if borrowers are rationed during crunches. These findings suggest either that the observed stickiness in the other regressions is largely unrelated to credit rationing or that the EcksteinSinai credit crunches do not correspond well with rationing periods. ${ }^{13}$ The results for nominal rates shown in the corresponding columns in table 3 largely replicate those in table 2 , with the exception that commitment loans display somewhat less stickiness than noncommitment loans.

The finding that stickiness on commitment loans is substantial and is nearly the same as that on noncommitment loans of the same rate type suggests that the empirical literature that equated stickiness with credit rationing may be misleading. A large portion of all rate stickiness is accounted for by commitment loans and cannot be associated with credit rationing because commitment contracts preclude rationing. In addition, if the stickiness is caused by Stiglitz and Weiss-type information problems, we would expect rates on commitment loans to be less sticky than those on noncommitment loans, given the empirical results cited earlier and corroborated here that commitments are associated with higher than average quality borrowers who likely have relatively few information problems. ${ }^{14}$ Therefore, the finding of

${ }^{13}$ One possible nonrationing explanation for the positive relationship between loan rate premia and $\mathrm{CRUNCH}$ is that $\mathrm{CRUNCH}$ may be coincident with periods of increased aggregate risk and, therefore, higher risk premia on bank loans.

${ }^{14}$ The rate premium is lower on commitment loans, ceteris paribus, by 30 basis points when the regression in col. 1 of table 2 is used, suggesting less compensation 
near-equality of stickiness between commitment and noncommitment loan rates suggests that information problems are not the dominant reasons for rate stickiness.

The finding that stickiness is much more prevalent on fixed-rate than floating-rate loans has no direct implications for credit rationing but may be consistent with an alternative hypothesis. If lenders provide implicit interest rate insurance, this result suggests that they do so through fixed-rate loan contracts that insulate the borrowers from rate variation over the life of the contract. ${ }^{15}$

The results shown in columns 4 and 5 of tables 2 and 3 replicate the models shown in columns 2 and 3 , respectively, except that COLLAT replaces COMMIT in all the interaction terms. The results again show that rates on fixed-rate loans are stickier than those on floatingrate loans. They also again show that stickiness is generally less during CRUNCH periods, contrary to the predictions of the extant theories of credit rationing. The new result is that secured loans exhibit more rate stickiness than other loans with the same floating- or fixed-rate status in most cases, although the difference is often slight. ${ }^{16}$ If information problems are driving the rate stickiness, then the slightly greater stickiness of secured loan rates suggests that borrowers who pledge collateral have more information problems than other borrowers (consistent with their greater risk discussed above) and that the process of pledging collateral does not fully offset these problems.

We also reran the main regressions using rates of growth of aggregate loans in place of the TRATE variables as alternative measures of credit market tightness (not shown). The results suggested that increasing credit tightness by reducing loan growth from its mean to zero actually results in slightly higher loan rate premia, contrary to the implications of credit rationing. The fact that loan rate premia do not consistently decline with alternative measures of credit market tightness (CRUNCH and reduced loan growth) suggests that rationing does not play an important role during periods of overall credit market tightness. This makes it more difficult to argue that credit rationing is an important macroeconomic phenomenon.

The stickiness data may also be used to examine Riley's (1987) version of credit rationing, which suggests that rationing would be

for risk on commitment loans, consistent with Avery and Berger (1991). Similar results hold when the other regressions are used.

${ }^{15}$ Some of the observed stickiness on fixed-rate loans may occur because the rates have been locked in by fixed-rate commitment contracts issued in the past. Unfortunately, this cannot be determined from the data, which have information on whether the loan is fixed-rate, but not on whether the commitment is fixed-rate.

${ }^{16}$ This comes from comparing the effects of COL-FLOAT with NOCOL-FLOAT and COL-FIXED with NOCOL-FIXED. 
substantial only for the marginal class of observably distinct risk pools. If differences across rate premia at a given time largely reflect risk differentials, then the stickiness results shown in tables 2 and 3 would hold primarily for the loans with the highest premia (i.e., highest risk) under Riley's hypothesis. To examine this possibility, the data were ordered by PREM for each time period, separated into quintiles, and grouped with data from the same quintiles from all the other time periods. Rerunning the regressions separately for each quintile group showed that the stickiness prevailed over all five quintiles. When a difference appeared, the most stickiness was observed in the lowest-premium (i.e., safest) quintile and the least stickiness in the highest (i.e., riskiest) quintile. These results run contrary to the predictions of Riley's model. They also provide a robustness check of the main stickiness results, which prevail across different premia levels.

One final insight from the stickiness analysis comes from examination of the raw data on PREM. The data reveal that banks at times extend loans with interest rates below the comparable risk-free rate. To investigate this, we identify loans for which the rate is at least 1 percent below the comparable risk-free rate (i.e., PREM $<-.01$ ) to guard against overmeasuring negative premia lending. While these negative-premium loans are only 1.0 percent of the entire sample, their proportion varies directly with the interest rate cycle. They peaked at 7.0 percent of the sample when open-market rates were at their peak in 1982:2, more than 70 times as high as in the mid to late 1980 s when open-market rates were substantially lower. The incidence of negative-premia loans is also more than 10 times as great on fixed-rate loans as on floating-rate loans, 2.3 percent versus 0.2 percent, respectively. These data are not consistent with extant theories of credit rationing, which require that banks earn a nonnegative expected economic profit on each loan by charging a rate sufficiently above the risk-free rate to compensate for expected credit losses. However, lending at a negative premium is consistent with other explanations of stickiness that recognize long-term lending relationships, such as implicit interest rate insurance or recontracting with financially distressed borrowers.

Overall, the stickiness results suggest that the empirical literature that equated stickiness with credit rationing may have been misleading because of the lack of available information on specific loan contract terms. With the notable exception of some of the collateral results, the data generally do not support the currently available theories of credit rationing as the dominant explanations of the stickiness. Nearly half of the observed stickiness occurs on commitment loans that cannot be symptomatic of rationing of this pool of borrowers, since they are contractually protected from rationing. Similarly, the 
portion of stickiness that is due to negative rate premia cannot reflect equilibrium credit rationing, which requires a nonnegative expected profit on each loan. The near-equality of stickiness on commitment and noncommitment loans casts additional doubt on whether information problems are major causes of stickiness, given the evidence in the literature that commitment loans are relatively safe and are likely associated with relatively few information problems. In addition, the finding that loan rate premia generally do not decrease in response to alternative measures of credit market tightness also casts doubts on whether the observed stickiness is symptomatic of credit rationing. ${ }^{17}$

\section{Proportions Test Results}

Tables 4 and 5 give the results for the proportions tests using real and nominal Treasury rates, respectively. The dependent variables are log-odds ratios $(\ln [Y /(1-Y)])$ for the three important loan characteristics, COMMIT, COLLAT, and FLOAT. The exogenous variables are the same as those in the stickiness tests, except that all loan variables are size-duration weighted and no interaction terms are specified. Column 1 of tables 4 and 5 shows the regressions for the probabilities that a dollar-year of loans will be made under commitment as functions of real and nominal rates, respectively; column 2 of both tables adds the CRUNCH variable. As discussed above, if credit rationing is an important macroeconomic phenomenon, then it is a virtual necessary condition that the proportion of new loans issued under commitment be substantially higher when rates are high. As shown in the bottom section of column 1 in table 4, a doubling of real rates yields a .069 increase in the log-odds ratio $\ln [\mathrm{COMMIT} /(1$ - COMMIT)]. As also shown, this translates into an increase in the probability of COMMIT of 1.7 percent when evaluated at the mean probability of COMMIT of 49.7 percent. ${ }^{18}$ Note

${ }^{17}$ It is interesting to note that the type of stickiness found here does not appear to carry over to corporate bond rates, suggesting that bank loan rates may be special in this regard. Lamy and Thompson (1988) found that the rate premium on primary issue corporate bonds increased rather than decreased with Treasury rates in a model in which risk (as measured by bond ratings) was controlled for and interacted with changes in Treasury rates. Their procedure is similar to our interactions between loan contract features and TRATE.

${ }_{18}$ The change in probability from changing exogenous variables in a logit equation is given by

$$
P_{1}-P_{0}=\frac{\exp \left(L_{0}+\Delta L\right)}{1+\exp \left(L_{0}+\Delta L\right)}-P_{0}
$$

where $P_{1}$ and $P_{0}$ are the new and initial probabilities, $L_{0}$ is the $\log$-odds ratio $\ln \left[P_{0} /(1-\right.$ $\left.P_{0}\right]$, and $\Delta L$ is the predicted change in the log-odds ratio from changing the exogenous variables. 
TABL.F. 4

Grouled Logit Regressions of the Probabilitues of Different loan Contract Terms on Reat. Interest Rates and Control. Vakiables

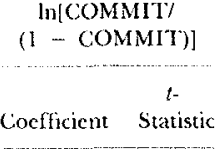

VARIABLE

TRATER

TRATER2

CRUNCH

COMMTT

COLLAT

FLOAT

$i^{2}$$$
\text { (1) }
$$$$
65.5894 * \quad 5.90
$$

$\begin{array}{ll}.0464 & 1.05 \\ .2896^{* *} & 7.55\end{array}$

.12

$$
\begin{gathered}
\ln [\text { COMMrTy } \\
(1-\text { COMMIT)] } \\
\text { Coefficient Statistic }
\end{gathered}
$$$$
\text { (2) }
$$

$$
-2.1449^{*} \quad-2.04
$$

$-.9288-.85$

$61.3072^{* *} \quad 5.49$

$-.1393 * *-4.28$

$\begin{array}{ll}.0741 & 1.66 \\ .3019^{* *} & 7.85\end{array}$

$.3019 * * \quad 7.85$

.12

$\begin{gathered}\ln [\text { COLLAT } \\ (1-\text { COLLAT })]\end{gathered}$
Coefficient Statistic

(3)

15.3677

1.31

$.1131 \% * \quad 2.97$

$4397 * \quad 13.38$

.17

$\begin{gathered}\ln [\text { COLLATY } \\ (1-\text { COLLAT })]\end{gathered}$
Goefficient Stotistic

(4)

$-4.2401 * *-3.76$

$-6.1881^{*}$

$19.8048-5.36$

$2553 *-1.69$

$.2553 * * \quad 7.70$

$.4093 \%$

18

12.40

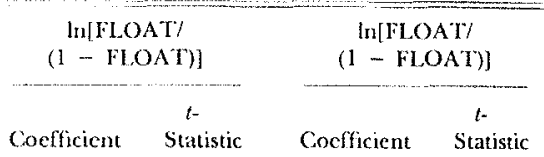

Coefficient Statistic

(5)

$-10.2090^{*} \quad-8.23$

$83.9995 * * 6.59$

(6)

(6)

$0826^{*} \quad 2.05$

$.8240 * * \quad 17.59$

$-11.2191 * *-8.83$

$86.4415^{* *} \quad 6.78$

$.1323 * * \quad 3.64$

\begin{tabular}{|c|c|c|c|c|c|c|c|c|c|}
\hline $.0694^{* * *}$ & 6.19 & $.0917^{* *}$ & 7.43 & $-.0772 * *$ & -6.50 & $-.1176 * *$ & -9.08 & $-.0977 * *$ & $-.1184 * * \quad-8.39$ \\
\hline
\end{tabular}

$.0818^{*} \quad 2.03$

$.7988 * * \quad 16.87$

Simulated Effects of an Increase in Credit Market lightness:

Predicted Change in Dependent Variable and t-Statistic from a Doubling of TRATER from Its Mean (from .0250 to .0500)

Change in the I'robability of the Category at Its Mean from a Doubling of 'TRATER

.0173 .0229

$$
-.0193 \quad-.0293
$$

$-0241$

$-.0296$

Predicted Change in Dependent Variable and t-Statistic from a Credit Canch (CRUNCH)

$$
\begin{aligned}
-.1393^{* *} & -1.28 \\
& \text { Change in the Probability of the Category at Its Mean from a Credit Crunch }
\end{aligned}
$$

$$
-.0348
$$$$
.0627
$$

Norr,-Fach olsservation represents the size-dumation weighted terms for a bank-date combination. Fich dependent variable is lnf $1 /(1-Y)]$, where $Y$ is the size-duration weighted proportion

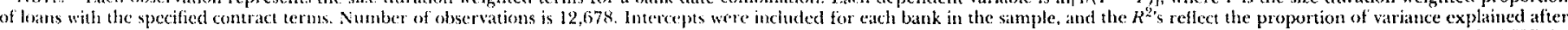

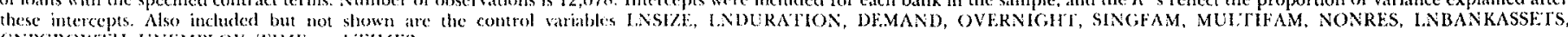
GNPCBOWlI, ENFMPIOY, TIMF, and TIMF2.

* Statistically significant at the 5 percent level, two-sided.

** Statistically significant at the I percent level, two-sided. 
that this 1.7 percent is effectively an estimate of the maximum effect of a doubling of real rates, since the logit specification yields the maximum derivatives at a $\mathbf{5 0}$ percent probability, with smaller effects toward the limiting probabilities of zero and 100 percent. The CRUNCH variable in column 2 of table 4 again goes in the opposite direction of that predicted by rationing and actually has a larger absolute effect $(-3.5$ percent) than the doubling of real rates. Similarly, when the rate of real or nominal aggregate loan growth was substituted for TRATER, the predicted effect from decreasing loan growth from the mean to zero actually reduced the probability of COMMIT, contrary to the implications of credit rationing (not shown). The effects of nominal rates shown in columns 1 and 2 of table 5 show a decrease in the probability of COMMIT of about 1 percent, with both CRUNCH and nominal loan growth (not shown) also predicting a decrease in COMMIT when markets are tight. Thus in all but one of six cases, the COMMIT probability moves in the opposite direction of that predicted by rationing theory, and the one exception is a very small increase.

Figure 2 illustrates the relationships between the COMMIT/NONCOMMIT ratio and Treasury rates over time. The solid lines in the figure connect the size-duration weighted averages of the COMMIT/ NONCOMMIT ratio for each time period, and the broken lines connect the weighted averages of TRATER and TRATEN. The ratio is negatively correlated with both real and nominal rates over the 1979:4-1982:4 period and is either positively correlated or uncorrelated with open-market rates for the remainder of the sample. This runs counter to the empirical predictions of the credit rationing hypothesis since cyclical rationing would be most likely to appear during the volatile period in which real interest rates went up and down from their sample maximum levels. However, it should be noted that when the sample was split into early and late subsamples and the regressions were rerun (not shown), the computed effects of TRATE on COMMIT/NONCOMMIT remained about the same as those reported in tables 4 and 5 , apparently because of changes in the control variables. $^{19}$

For additional evidence, the COMMIT regressions in tables 4 and 5 were also rerun using as dependent variables the quantities of commitment and noncommitment loans in place of the log-odds ratios (not reported in the tables). Both types of loans were found to be increasing in the interest rate, suggesting that both commitment and noncommitment borrowers are able to obtain funding when rates are

${ }^{19}$ The fact that the results hold up by subsample also lessens concern over the possible nonstationarity of the COMMIT ratio over the late subsample. 


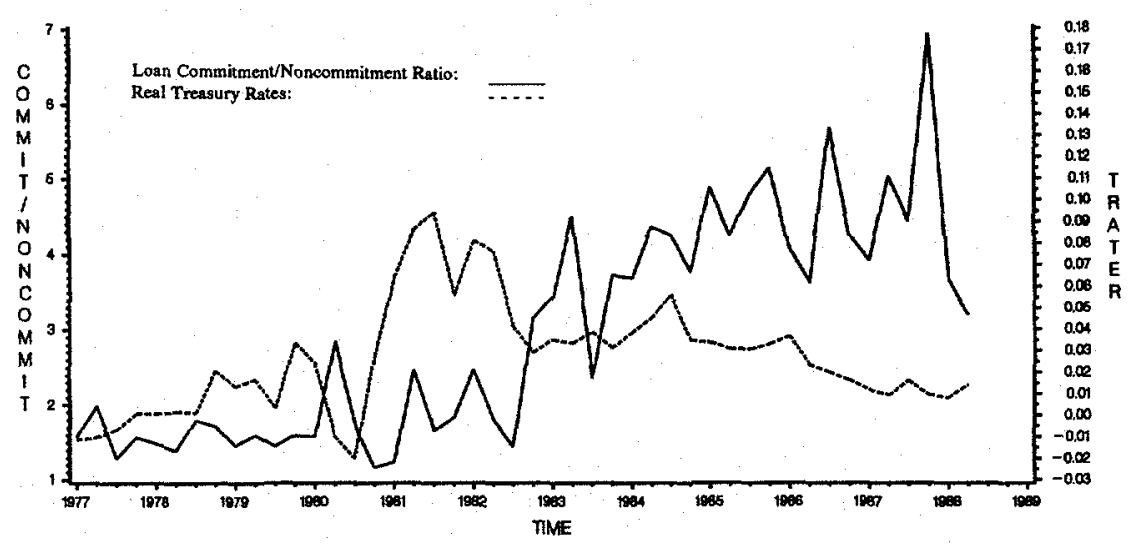

b

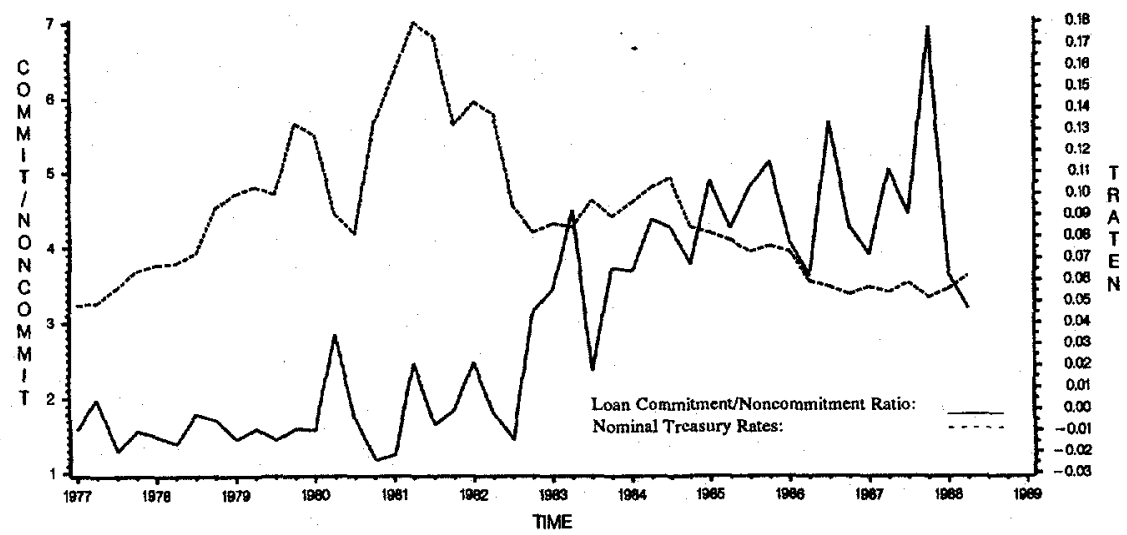

FIG. 2.-Ratio of commitment to noncommitment bank loans and Treasury rates of the same duration (1977:1-1988:2): $a$, real Treasury rates; $b$, nominal Treasury rates.

high. Thus even if some noncommitment borrower pools are subject to rationing, these data suggest that other noncommitment borrower pools increase their borrowing, more than offsetting any rationing effect in the aggregate. ${ }^{20}$

The log-odds and quantity COMMIT regressions together suggest that information-based, equilibrium credit rationing, if it exists, may be relatively small and economically insignificant. The one small in-

${ }^{20}$ The log-odds logit formulation is still preferred to using the quantities as dependent variables because the logit form automatically controls for any variables that affect the overall level of lending by the bank. 
crease in the commitment proportion from a doubling of real interest rates is counteracted by the opposite findings when nominal interest rates, CRUNCH, or loan growth is specified and by the finding that the quantity of noncommitment loans actually increases with both real and nominal rates. In addition, as discussed above, there are two other related explanations that are just as likely to account for the single small commitment proportion increase. First, when market rates are high, borrowers who have both commitment and noncommitment funding capacities may switch from noncommitment to commitment sources to avoid rationing. Second, borrowers may take out more commitment contracts when rates are rising to avoid rationing. Thus the one small increase in the commitment proportion when real open-market rates increase may indicate that Stiglitz and Weiss-type information problems are operative, but the extent to which they result in rationing or just more commitment protection from rationing is not identified.

The results and conclusions drawn here are somewhat in conflict with those of Sofianos et al. (1990), but this conflict is likely due to methodological differences and the fact that they used only aggregate data. Sofianos et al. ran vector autoregressive models of the dollar stocks (as opposed to new flows) of commitment and noncommitment loans aggregated from a sample of banks. They found that with lags of the interest rate included in the regressions, the coefficients of the lagged money stock were statistically significant in predicting (i.e., Granger-caused) noncommitment loans but were not statistically significant in predicting (i.e., did not Granger-cause) commitment loans. Sofianos et al. took this as evidence that a rationing channel acts on noncommitment loans but not on commitment loans. In subsequent runs provided by those authors, however, the sum of the lagged coefficients of the money stock was positive and statistically significant for commitment loans and negative and insignificant for noncommitment loans. These additional results conflict with a conclusion of credit rationing since it is noncommitment loans rather than commitment loans that should increase with the money stock for a given interest rate under rationing. To investigate these implications further, we reran our log-odds COMMIT models, adding lagged changes in the real money stock as exogenous variables (not shown in the tables). The sums of the money lags were positive and significant when real interest rates were included as regressors (positive and insignificant when nominal rates were included), again running contrary to the predictions of credit rationing.

Columns 3 and 4 of tables 4 and 5 show that the probability of collateralized borrowing decreases by about $1-2$ percent when openmarket rates increase by 2.5 percent. Again, CRUNCH has the oppo- 
site effect of market rates. These findings are consistent with the stickiness results, which suggested that even after the pledging process, the remaining information problems are greater than average for the pools of borrowers in which collateral is pledged. These results also suggest that to the extent that rationing occurs, secured borrowers are more often rationed than unsecured borrowers. However, rerunning the regressions using the quantities of secured and unsecured loans as the dependent variables in place of the log-odds ratio (not shown in the tables) indicated that both secured and unsecured loans tend to increase when rates are high. This suggests that the rationing of secured borrowers, if it occurs, may not have much macroeconomic significance since other secured borrowers apparently make up the difference by increasing their borrowing.

The final columns in tables 4 and 5 show the regressions for the probability of FLOAT. The results show a small decrease in the FLOAT proportion of about 1-3 percent when open-market rates increase by 2.5 percent. This provides some weak evidence for the implicit interest rate insurance hypothesis to the extent that a fixedrate loan is a superior vehicle to a floating-rate loan for providing this insurance. Rerunning the regressions using the quantities of floating-rate and fixed-rate loans as dependent variables (not shown in the tables) yielded a prediction that both types of loans increase with open-market rates.

Overall, the proportions tests suggest that credit rationing of commercial bank loan customers is not likely to be an important macroeconomic phenomenon. The proportion of new loans issued under commitment does not increase substantially when real rates rise and actually decreases when most of the measures of credit market tightness increase, despite the fact that rationing can occur only by decreasing noncommitment loans. Moreover, the slight increase in the commitment proportion in the real rate regression appears to come about not because of a decrease in noncommitment loans, but simply because noncommitment loans increase by less than commitment loans do when interest rates increase. Increases in the money stock for a given interest rate also tend to increase commitment loans more than noncommitment loans, again contrary to the predictions of credit rationing.

Finally, we note that both the stickiness and proportions tests were subjected to a number of robustness checks beyond those reported above. The regressions were rerun using data from 1977 through 1983 , leaving off the $1984-88$ period, when it is generally agreed that rationing would be less severe or nonexistent. The results were qualitatively unaffected by this data omission. The stickiness regressions were rerun using the 3-month Treasury rate for every loan 
rather than the comparable Treasury rate for the loan, and most of the results were similar. The stickiness regressions were also rerun with the TRATE variable interacted with LNSIZE, and with dummy variables for whether rates were increasing or decreasing. These interactions did not change the results qualitatively. ${ }^{21}$ The proportions regressions for the three key contract terms were also rerun with each of the other two contract terms excluded as regressors, with no qualitative change in results.

\section{Conclusions}

This paper has examined the empirical significance of informationbased, equilibrium credit rationing of commercial bank loan customers by focusing on specific elements of the commercial loan contract. Such an analysis is suggested by the extant theories of credit rationing, which offer a variety of testable implications vis-à-vis specific loan contract features, particularly commitments. Earlier empirical studies have been unable to examine these implications because information on loan contract features has generally been unavailable.

Our major empirical results and their implications are summarized in table 6. As in earlier studies, our results suggest that the commercial loan rate is sticky with respect to open-market rates, consistent with rationing. In contrast to other studies, however, use of the data on the key loan contract terms suggests that most of the stickiness does not reflect credit rationing. Nearly half of the observed loan rate stickiness occurs on loans made to commitment borrowers, who are contractually protected from rationing. Some of the remaining stickiness involves loans whose rate premia actually become negative when open-market rates are high, which also cannot be symptomatic of equilibrium credit rationing. Also in contrast to other studies, we are able to verify the robustness of our results using alternative measures of credit market tightness.

The most compelling evidence on rationing concerns the proportion of new loans made under commitment. Rationing requires that the fraction of new loans under commitment rise when open-market rates are high, since noncommitment borrowers are rationed and commitment borrowers are not. Our results suggest that this phenomenon does not occur to any great extent, and, in fact, the commitment ratio decreases with most of our measures of credit market tightness. The data also indicate that all types of commercial loans,

${ }^{21}$ The TR-LNSIZE interaction had a positive coefficient, consistent with the hypothesis that smaller loans may have more information problems that are reflected in a larger degree of rate stickiness. 
TABLE 6

Summary of Major Empirical Results and Their Implications

Result

Implication

\section{A. Stickiness Tests}

1. General stickiness. Loan rate premia over Treasury rates of equal duration decrease substantially with open-market rates

2. Commitment loan rates nearly as sticky as noncommitment rates. Also, some of the observed stickiness occurs on loans with negative premia over risk-free rates

3. Fixed-rate loans have much stickier rates than floating-rate loans

4. Secured loans have slightly stickier rates than unsecured loans

5. Loan rate premia generally do not decrease with other measures of credit market tightness (CRUNCH or reduced aggregate loan growth)

6. Loan rate stickiness prevails over all risk class quintiles (as measured by rate premia)
Consistent with credit rationing, implicit interest rate insurance, or recontracting with troubled borrowers

Much of the stickiness cannot be explained by credit rationing since commitment borrowers cannot be rationed, and negative premia are inconsistent with equilibrium rationing theories

Consistent with implicit interest rate insurance hypothesis

Consistent with credit rationing since collateral is more often required from riskier, more informationproblematic borrower pools

Credit rationing, if it occurs, does not play an important role during periods of overall credit market tightness

Inconsistent with Riley (1987) version of credit rationing, in which only the observably riskiest pools are rationed.

\section{B. Proportions Tests}

1. Commitment proportion of new loans does not increase substantially with real open-market rates and decreases with nominal rates and other measures of market tightness

2. The quantities of both new commitment loans and new noncommitment loans increase with openmarket rates

3. Commitment proportion of new loans increases with lagged money stock, given interest rates

4. Collateral proportion of new loans decreases slightly with open-market rates, but quantities of both new secured and new unsecured loans increase

5. Fixed-rate proportion of new loans increases slightly with market rates
Inconsistent with credit rationing having macroeconomic significance because only noncommitment borrowers can be rationed

Inconsistent with credit rationing having macroeconomic significance. If some noncommitment borrowers are rationed, others increase borrowing and make up for it

Inconsistent with credit rationing, which predicts that money channel (i.e., rationing) affects only noncommitment loans

Consistent with greater relative rationing of riskier borrowers, but others increase borrowing, and make up for it

Consistent with implicit interest rate insurance hypothesis 
including noncommitment loans, tend to increase in quantity during periods of high interest rates. This suggests that to the extent that some borrowers may be rationed, others take their places and receive bank loans. Taken together, the results in this paper do not rule out the existence of information-based equilibrium credit rationing of commercial bank borrowers, but they make it difficult to argue that such rationing constitutes an important macroeconomic phenomenon.

\section{References}

Avery, Robert B., and Berger, Allen N. "Loan Commitments and Bank Risk Exposure." J. Banking and Finance 15 (February 1991): 173-92.

Berger, Allen N., and Udell, Gregory F. "Some Evidence on the Empirical Significance of Credit Rationing." Finance and Economics Discussion Series, no. 105. Washington: Bd. Governors, Fed. Reserve System, December 1989.

- "Collateral, Loan Quality, and Bank Risk."J. Monetary Econ. 25 (January 1990): $21-42$.

- "Securitization, Risk, and the Liquidity Problem in Banking." In Structural Change in Banking, edited by Michael Klausner and Lawrence J. White. Homewood, Ill.: Irwin, 1992, in press.

Berkovitch, Elazar, and Greenbaum, Stuart I. "The Loan Commitment as an Optimal Financing Contract." J. Financial and Quantitative Analysis 26 (March 1991): 83-95.

Besanko, David, and Thakor, Anjan V. "Collateral and Rationing: Sorting Equilibria in Monopolistic and Competitive Credit Markets." Internat. Econ. Rez. 28 (October 1987): 671-89. (a)

- . "Competitive Equilibrium in the Credit Market under Asymmetric Information." J. Econ. Theory 42 (June 1987): 167-82. (b)

Bester, Helmut. "Screening vs. Rationing in Credit Markets with Imperfect Information." A.E.R. 75 (September 1985): 850-55.

Blinder, Alan S., and Stiglitz, Joseph E. "Money, Credit Constraints, and Economic Activity." A.E.R. Papers and Proc. 73 (May 1983): 297-302.

Board of Governors of the Federal Reserve System. "Senior Loan Officer Opinion Survey on Bank Lending Practices." Washington: Bd. Governors, Fed. Reserve System, May 1988.

Boot, Arnoud W. A., and Thakor, Anjan V. "Dynamic Equilibrium in a Competitive Credit Market: Intertemporal Contracting as Insurance against Rationing." Working paper. Bloomington: Indiana Univ., August 1989.

Boot, Arnoud W. A.; Thakor, Anjan V.; and Udell, Gregory F. "Competition, Risk Neutrality and Loan Commitments." J. Banking and Finance 11 (September 1987): 449-71.

Chan, Yuk-Shee, and Kanatas, George. "Asymmetric Valuations and the Role of Collateral in Loan Agreements." J. Money, Credit and Banking 17 (February 1985): 84-95.

Duca, John V., and Rosenthal, Stuart S. "An Empirical Test of Credit Rationing in the Mortgage Market."J. Urban Econ. 29 (March 1991): 218-34.

Eckstein, Otto, and Sinai, Alan. "The Mechanisms of the Business Cycle in 
the Postwar Era." In The American Business: Continuity and Change, edited by Robert J. Gordon. Chicago: Univ. Chicago Press (for NBER), 1986.

Fried, Joel, and Howitt, Peter. "Credit Rationing and Implicit Contract Theory." J. Money, Credit and Banking 12 (August 1980): 471-87.

Goldfeld, Steven M. Commercial Bank Behavior and Economic Activity: A Structural Study of Monetary Policy in the Postwar United States. Amsterdam: NorthHolland, 1966.

Hendershott, Patric H. "Real User Costs and the Demand for Single-Family Housing." Brookings Papers Econ. Activity, no. 2 (1980), pp. 401-44.

Jaffee, Dwight M. Credit Rationing and the Commercial Loan Market. New York: Wiley, 1971.

Jaffee, Dwight M., and Rosen, Kenneth T. "Mortgage Credit Availability and Residential Construction." Brookings Papers Econ. Activity, no. 2 (1979), pp. 333-76.

Jaffee, Dwight M., and Russell, Thomas. "Imperfect Information, Uncertainty, and Credit Rationing." Q.J.E. 90 (November 1976): 651-66.

Kanatas, George. "Commercial Paper, Bank Reserve Requirements, and the Informational Role of Loan Commitments." J. Banking and Finance 11 (September 1987): 425-48.

Kareken, John H. "Lenders' Preferences, Credit Rationing, and the Effectiveness of Monetary Policy." Rev. Econ. and Statis. 39 (August 1957): 292-302.

King, Stephen R. "Monetary Transmission: Through Bank Loans or Bank Liabilities?" J. Money, Credit and Banking 18 (August 1986): 290-303.

Lamy, Robert E., and Thompson, G. Rodney. "Risk Premia and the Pricing of Primary Issue Bonds." J. Banking and Finance 12 (December 1988): $585-601$.

Melnik, Arie, and Plaut, Steven E. "Loan Commitment Contracts, Terms of Lending, and Credit Allocation." J. Finance 41 (June 1986): 425-35.

Riley, John G. "Credit Rationing: A Further Remark." A.E.R. 77 (March 1987): 224-27.

Rosen, Harvey S., and Rosen, Kenneth T. "Federal Taxes and Homeownership: Evidence from Time Series." J.P.E. 88 (February 1980): 59-75.

Scott, Ira O., Jr. "The Availability Doctrine: Theoretical Underpinnings." Rev. Econ. Studies 25 (October 1957): 41-48.

Sharpe, Steven A. "Credit Rationing, Concessionary Lending, and Debt Maturity." J. Banking and Finance 15 (June 1991): 581-604.

Slovin, Myron B., and Sushka, Marie E. "A Model of the Commercial Loan Rate." J. Finance 38 (December 1983): 1583-96.

Sofianos, George; Wachtel, Paul A.; and Melnik, Arie. "Loan Commitments and Monetary Policy." J. Banking and Finance 14 (October 1990): 677-89.

Stiglitz, Joseph E., and Weiss, Andrew. "Credit Rationing in Markets with Imperfect Information." A.E.R. 71 (June 1981): 393-410.

- "Credit Rationing: Reply." A.E.R. 77 (March 1987): 228-31.

Thakor, Anjan V., and Udell, Gregory F. "An Economic Rationale for the Pricing Structure of Bank Loan Commitments." J. Banking and Finance 11 (June 1987): 271-89.

Wette, Hildegard C. "Collateral in Credit Rationing in Markets with Imperfect Information: Note." A.E.R. 73 (June 1983): 442-45.

Williamson, Stephen D. "Costly Monitoring, Loan Contracts, and Equilibrium Credit Rationing." Q.J.E. 102 (February 1987): 135-45. 